DOI: https://doi.org/10.15407/techned2018.04 $: \underline{029}$

\title{
MITIGATION OF THREE-PHASE POWER LINE MAGNETIC FIELD BY GRID ELECTROMAGNETIC SHIELD
}

Journal

Publisher

ISSN

Issue

Pages
Tekhnichna elektrodynamika

Institute of Electrodynamics National Academy of Science of Ukraine 1607-7970 (print), 2218-1903 (online)

No 4, 2018 (July/August)

$29-32$

\section{Author}

\section{V.S. Grinchenko*}

State Institution "Institute of Technical Problems of Magnetism of the National Academy of

Sciences of Ukraine",

19, Industrialna st., Kharkiv, 61106, Ukraine,

e-mail: vsgrinchenko@gmail.com

* ORCID ID : http://orcid.org/0000-0002-6195-3011

\section{Abstract}

This paper deals with the mitigation of the three-phase power line magnetic field by a grid electromagnetic shield. The shield is made of a set of wires located in the same plane and connected in parallel. Shielding characteristics of three equivalent metal capacity grid shields, consisting different number of wires and having different wire cross-sections and different distances between wires, is studied by numerical simulation. To justify the possibility of the three-phase power line magnetic field mitigation, the magnetic field distributions for a grid shield and an equivalent metal capacity flat shield are calculated. References 10, figures 5. 
Key words: power line, magnetic field, shielding, electromagnetic shield, grid shield, simulation.

Received: 06.03.2018

Accepted: 14.03.2018

Published:

\section{References}

1. Rezinkina M.M., Grinchenko V.S. Usage of electromagnetic shields for power frequency magnetic field mitigation in power industry. Tekhnichna Elektrodynamika. 2012. № 3. Pp. 15-16. (Rus)

2. Rezinkina M.M., Shcherba A.A., Grinchenko V.S., Rezinkina K.O. Calculation choice of parameters of electromagnetic screens of complicated three-dimensional configuration. Tekhni chna Elektrodynamika

. 2012. No 1. Pp. 10-16. (Rus)

3. Bavastro D., Canova A., Freschi F., Giaccone L., Manca M. Magnetic field mitigation at power frequency: design principles and case studies. IEEE Transactions on Industry Applications . 2015. Vol. 51. No 3. Pp. 2009-2016. DOI:

4. Burnett J., Du Yaping P. Mitigation of extremely low frequency magnetic fields from electrical installations in high-rise buildings. Building and Environment. 2002. Vol. 37. No 8-9. Pp. 769-775. DOI:

//doi.org/10.1016/S0360-1323(02)00043-4

https:

5. Canova A., Bavastro D., Freschi F., Giaccone L., Repetto M. Magnetic shielding solutions for the junction zone of high voltage underground power lines. Electric Power Systems 
Research .2012. No 89. Pp.

109-115. DOI:

https:/

/doi.org/10.1016/j.epsr.2012.03.003

6. Cruz Romero P.L., Del-Pino-López J.C. Magnetic field shielding of underground cable duct banks. Progress In Electromagnetics Research. 2013. No 138. Pp. 1-19.

7. De Wulf M., Wouters P., Sergeant P., Dupre L., Hoferlin E., Jacobs S., Harlet P.

Electromagnetic shielding of high-voltage cables. Journal of Magnetism and Magnetic Materials . 2007. No 316. Pp. 908-911. DOI:

https://doi.org/10.1016/j.jmmm.2007.03.137

8. Kaden H. Wirbelströme und Schirmung in der Nachrichtentechnik. Springer Berlin Heidelberg, 1959. DOI: https://doi.org/10.1007/978-3-540-32570-3

9. Rozov Volodymyr, Grinchenko Volodymyr. Simulation and analysis of power frequency electromagnetic field in buildings closed to overhead lines. 2017 IEEE First Ukraine Conference on Electrical and Computer Engineering

. 2017. Pp. 500-503. DOI:

https://doi.org/10.1109/UKRCON.2017.8100538

10. Salinas E., Rezinkina M., Atalaya J. Some 2D-3D aspects of shielding of longitudinal sources of extremely low frequency magnetic fields. The Environmentalist. 2009. Vol. 29. No 2. Pp. 141-146. DOI:

https://doi.org/10.1007/s10669-008-9206-0

\section{PDF}

